\title{
Sentetik tohum
}

\author{
Meltem Erdem*1 iD, Huseyin Uysal ${ }^{1}$ (iD \\ ${ }^{1}$ Aydın Adnan Menderes University, Faculty of Agriculture, Agricultural Biotechnology, 09970, Aydın, Türkiye
}

\section{$\ddot{O} \mathbf{z}$}

Sentetik tohum, besin maddesi ve koruyucu bileşikler içeren özel maddelerle kaplanmış somatik embriyolardır. Sentetik tohum üretimi, canlı tohum üretemeyen bitkiler için elverişlidir. Sentetik tohumdan bitki elde edilmesi, ilk kez doku kültüründen elde edilen somatik embriyodan suyun uzaklaştırılması yoluyla yapılmıştır. Somatik embriyo kaplanmasında sodyum alginat veya alginik asit matriksleri çok yaygın olarak kullanılmaktadır. Bitki çoğaltımının kolay olması, uzun süre saklanabilmesi, nesli tükenmekte olan bitkilerin neslinin devam ettirilmesi ve üretimlerinin düşük maliyetle yapılabilmesi gibi birçok avantaj sentetik tohumun bitkilerin gelişimi için önemli ölçüde kullanılabilirliğini göstermektedir. Sentetik tohum teknolojisi tohumla çoğaltım imkanı bulunmayan bitkilerin üretiminde de kullanılabilecek çok önemli bir tekniktir. Bu derleme makale, sentetik tohum konusundaki ortaya koyulmuş bilgileri ve yapılmış çalışmaları bir araya getirmek amacıyla yazılmıştır.

Anahtar kelimeler: Bitki rejenerasyonu; in vitro kültür; sentetik tohum; somatik embriyo

\section{Synthetic seed}

\begin{abstract}
Synthetic seeds are somatic embryos coated with special substances containing preservative compounds. Synthetic seed production has been useful for plants that cannot produce viable seeds. Plant formation from synthetic seed was first made by removing water from the somatic embryo obtained from tissue culture. Sodium alginate or alginic acid matrices are commonly used for somatic embryo coating. Many advantages such as easy plant propagation, long-term storage, perpetuation of endangered plants and low cost production show the significant usability of synthetic seed for the development of plants. Synthetic seed technology is a very important technique that can be used in the production of plants that cannot be reproduced by seed. This review article was written to bring together the information and studies on synthetic seed.
\end{abstract}

Keywords: In vitro culture; plant regeneration; somatic embryo; synthetic seed

\section{Giriş}

Sentetik tohum, besin maddesi ve koruyucu bileşikler içeren özel maddelerle kaplanmış somatik embriyolardır (Kurt, 2015). Özellikle tohumla üretimin sınırlı olduğu bitkiler için son derece kullanışlı bir teknik olan bu yöntem, üreme organları dışında tohum benzeri yapıların elde edilmesi ile tohumla üretime benzer özellik göstermektedir. Sentetik tohum üretiminde somatik embriyoların kaplanmasında düşük maliyeti, düşük toksisitesi ve jel stabilitesi nedeniyle sodyum

\footnotetext{
* Sorumlu yazar.

E-mail: mhmeltemerdem@ hotmail.com (M. Erdem). https://doi.org/10.51753/flsrt.943981 Yazar katkılar1 Geliş tarihi 28 Mayıs 2021; Kabul tarihi 7 Ağustos 2021

Çevrimiçi yayın 30 Ağustos 2021

2718-062X (C) 2021 This is an open access article published by Dergipark under the CC BY license. 
alginat yaygın olarak kullanılmaktadır (Ghosh ve Haque, 2019). Sodyum alginat çözeltisindeki $\mathrm{Na}^{+}$ile kalsiyum klorür çözeltisindeki $\mathrm{Ca}_{2}{ }^{+}$arasındaki bir iyon değişim reaksiyonu çözünmeyen bir kalsiyum alginat tabakası oluşturur (Daud ve ark., 2008). Bu sayede somatik embriyo hem önemli ölçüde korunmakta, hem de tohum çimlenme aşamasında somatik embriyoya besin temini sağlanmaktadır. Bu teknik; temel olarak nesli tükenmekte olan türlerin, tıbbi ve ticari bitkilerin korunması ve çoğaltılması için önerilmektedir (Jang ve ark., 2020). Sentetik tohum üretim teknolojisi, mevcut in vitro kültür sistemlerine kıyasla eksplantların hayatta kalma oranını önemli ölçüde arttırmakta ve ucuz ve pratik bir doku kültürü üretim tekniği imkanı sunmaktadır (Singh ve ark., 2006; Kumar ve Thomas, 2012). Sentetik tohumu oluşturan biyolojik olarak parçalanabilir matris, eksplantları fiziksel hasarlardan ve dış çevre faktörlerinden etkili bir şekilde korur. Ayrıca erken büyüme için gerekli besinleri de içerdiği için somatik embriyo için bir endosperm görevi görmektedir (Jang ve ark., 2020). Bu derleme makalesinde sentetik tohum oluşumunda embriyo gelişimini sağlayan somatik embriyogenez yöntemi, sentetik tohum ve oluşumu ve bu teknolojideki bazı avantaj ve dezavantajlara değinilmiştir.

\section{Bitki doku kültürü ve somatik embriyogenez}

Steril şartlar altında ve yapay bir besi ortamında bitki, doku, hücre veya organ gibi bitki kısımlarının kullanılarak yeni bir doku, bitki, organ veya ürünlerin üretilmesi olayına bitki doku kültürü denilmektedir (Sokmen ve Gurel, 2001; Uysal ve ark., 2007). İlk doku kültürü çalışması 1902 yılında gerçekleştirilmiş olup sonraki yıllarda da doku kültüründe çeşitli başarılar sağlanmıştır. Ayrıca 1990 yılında sentetik tohum geliştirilmesiyle birlikte germplazm korunması çalışmalarına başlanmıştır. Son olarak 1995 yılında ise ilk rekombinant insan gıdası oluşturulmuş ve günümüzde de doku kültüründe çalışmalar başarılı bir şekilde yürütülmektedir (Kurt, 2015). Bitki biyoteknolojisinin önemli bir alanı olup steril koşullar altında ve geliştirilmiş besi ortamlarında kültüre alınarak dokulardan, hücrelerden veya tek bir hücreden in vitro koşullarda tam bir bitki oluşturulabilir (Oktem ve Yucel, 2012). Bitki doku kültürüne "Mikro üretim" veya "Aseptik kültür" de denilmektedir (Gonulsen, 1987).

Farklılaşmamış bitki hücreleri, uygun koşullar sağlanmasıyla steril ortamlarda kültüre alındığında yeni bitki/bitkicikler oluşturabilmektedirler (Mohammed ve ark., 2021). Steril koşullar altında bitki oluşumunu sağlayan bu materyallerin sahip oldukları yapısal fonksiyona "totipotensi" denilmektedir. Aslında totipotensinin, bitkisel hücre ve dokuların farklılaşarak yeni bitki meydana getirebilme yeteneği olduğu söylenebilir (Kurt, 2015). Bitki doku kültürü uygulamaları, bitkilerin hızlı bir şekilde klon olarak çoğaltılabilmesi, klasik metotlarla çoğaltımın kolay olmadığı bitkilerde çoğaltımın sağlanabilmesi, hastalık oluşturabilecek çeşitli faktörlerden arındırılmış bitkilerin elde edilmesi, bitki ıslahının etkinliğini arttıracak ve süresini kısaltacak çeşitli çalışmaların gerçekleştirilmesi, somaklonal varyasyonların meydana getirilmesi, haploid yapıda bitkilerin üretimi, bitki gen kaynaklarının muhafaza edilmesi ve sekonder metabolitler gibi biyokimyasal ürünlerin üretilmesi gibi çeşitli amaçlarla kullanılmaktadır (Tekin, 2015). Biyoteknolojik çalışmaların amacı, bitki ıslahının sürecini kısaltarak ıslah sürecine daha geniş bir varyasyon olanağı sağlamak, bu sayede daha kısa sürede daha iyi sonuçlar elde ederek verimin ve kalitenin arttırılmasıdır (Uysal, 2021). Böylece hem biyotik stres faktörleri etmenlerinden olan bakteri, virüs ve yabancı otlara karşı dayanıklı transgenik bitkiler oluşturulabilirken hem de kuraklık ve tuzluluk gibi abiyotik stres faktörlerine karş1 dayanıklı transgenik bitkiler gen aktarımıyla geliştirilmiştir (Arvas ve Kocacalıskan, 2020) Bitkinin somatik dokularından kapalı iletim sistemine sahip bipolar bir embriyonun üretilmesini sağlayan aseksüel gelişme süreci, somatik embriyogenez olarak adlandırılır (Ozcan ve ark., 2001; Cardoza, 2008). Somatik embriyogenez, doku kültürü sisteminin en çok kullanılan rejenerasyon yollarından birisidir ve bu teknik somatik hücrelerin embriyogenik gelişimi gerçekleştirebilme yeteneklerine dayanır (Ipekci, 2002). 1950'lerde bitki doku kültüründe kallus yapısından embriyo ve embriyoya benzeyen yapılar oluşsa bile somatik embriyogenez ilk defa 1958 yılında Steward ve arkadaşları tarafından havuçtaki somatik dokulardan gerçekleştirilmiştir. Günümüzde yapay kültür koşulunda ve özellikle bitkisel hormonların kullanımıyla bir bitki dokusu veya organında bulunan somatik hücreden ya direkt olarak ya da kallus yapısının meydana gelmesiyle indirekt olarak embriyo oluşabilmektedir (Babaoglu ve ark., 2001). Somatik doku hücreleri ilk olarak yüksek miktarda oksin (genelde 2,4-D), naftalin asetik asit, pikloram ve dikamba maddelerinin bulunduğu yapay ortamda kültüre alındıktan sonra oksin hormonunun bulunmadığı ikinci bir kültür ortamına aktarıldıklarında embriyo üretebilme yeteneğine sahip olurlar. Oksinlerin somatik bitki hücrelerine embriyo üretimi için yeniden zigotik bir kapasite kazandırdığ 1 belirtilmektedir (Monnier, 1990). Yapılan birçok çalışmada somatik embriyogenez elde etmek için MS (Murashige ve Skoog) kültür ortamının tercih edildiği görülmektedir (Murashige ve Skoog, 1962; Ipekci ve Gozukirmizi, 2003; Hussein ve ark., 2020; Mohammed ve ark., 2021).

Yapılan bazı araştırmalar özetlendiğinde Mikula ve arkadaşları tarafından Gentiana cruciata L. ve G. tibetica L. ile yapılan bir çalışmada en iyi somatik embriyo oluşumunun gerçekleştiği besi ortamları 1,49 $\mu \mathrm{mol} \mathrm{GA}_{3}, 4,64 \mu \mathrm{mol}$ Kinetin (KIN), $434 \mu \mathrm{mol}$ adenin sülfat hormonları içeren MS besi ortamı olduğunu bildirilmiştir (Mikula ve ark., 2005). Yine Gentiana cruciata L., Gentiana pannonica L. ve Gentiana tibetica L. türlerinde en yüksek miktarda somatik embriyo üretiminin 0,5 $\mathrm{mg} / \mathrm{l}$ oranlarında gibberellik asit $\left(\mathrm{GA}_{3}\right)$ ve naftalen asetik asit (NAA), $1.0 \mathrm{mg} / \mathrm{l}$ oranında da Kinetin içeren MS besi ortamı kombinasyonlarında görüldüğü rapor edilmiştir (Mikula ve Rybczyfiski, 2001). Paulownia elongata Mill. bitkisinin yaprak ve internod eksplantlarından somatik embriyo ve sentetik tohum elde etmek için yapılan çalışmada somatik embriyo oluşturma frekansının en yüksek $10 \mathrm{mg} / 1$ Thidiazuron (TDZ) hormonu içeren MS besi ortamında oluştuğu belirlenmiştir (Ipekci ve Gozukirmizi, 2003). Yine yonca bitkisinde en yüksek somatik embriyo veriminin 2,4-D oksini içeren MS besi ortamından sağlandığ 1 bildirilmiştir (Sule, 2005). Baltacı ve Arslan tarafından Oğulotu (Melissa officinalis) bitkisinde yapılan çalışmada ise somatik embriyo oluşumu amacıyla yine MS besi ortamı tercih edilmiş ve $0,5 \mathrm{mg} / \mathrm{l}$ oranında KIN içeren besi ortamında kallusların en iyi oranda somatik embriyo oluşturduğu belirlenmiştir (Baltaci ve Arslan, 2019).

Somatik embriyogenez; eksplant kaynağ1, genetik yap1, besi ortamındaki bitkisel hormonlar, azot kaynağı, çevre şartları ve bitkinin fizyolojik durumu gibi durumlardan etkilenmektir (Tisserat, 1985; Takamura ve ark., 1995; Schwenkel ve Winkelmann, 1998; Ozcan ve ark., 2001; Kocak ve ark., 2014). Somatik embriyo oluşumunun genotipe bağlı olması ve 
oluşturulan embriyo yapılarında düşük çimlenme oranı olması bu yöntemin kullanımını kısıtlayan etkenlerdendir (Jalali ve ark., 2012). Ancak bunlara rağmen aynı zamanda somatik embriyogenez; somatik hibridizasyon, partikül tabancası ve Agrobacterium tumefaciens aracılığı ile bitkilere gen aktarımı şeklinde önemli kullanım alanlarına sahip olmakla birlikte hızlı çoğaltım, sentetik tohum üretimi ve gen aktarımında oldukça önemli bir potansiyele sahip olmaktadır (Tisserat, 1985; Ozcan ve ark., 2001; Ozyigit ve Yucebilgili Kurtoglu, 2020).

Somatik embriyogenez doğrudan (direkt) ve dolaylı (indirekt) olarak iki şekilde gerçekleşmektedir. Doğrudan somatik embriyogenezde embriyolar eksplant yapılarından (preembriyojenik hücreler) meydana gelip aynı yapıda klon oluşturulur (Nakamura ve ark., 1992; Calheiros ve ark., 1994; Ibrahim ve ark., 2013). Olgunlaşmamış zigotik embriyolar doğrudan somatik embriyogenez gerçekleştirmede en çok kullanılan eksplantlardır (Finer, 1995). Dolaylı somatik embriyogenezde ise eksplantlar yüksek oranda oksin hormonu içeren besi ortamında kültüre alındığında embriyonik kallus ve bu yapı üzerinde proembriyolar oluşur. Daha sonra kallus yapısı oksin hormonunun bulunmadığı besi ortamına aktarılır ve daha önce oluşan proembriyolardan bipolar embriyoların oluşumunun ardından eğer şartlar elverişliyse bitkicikler meydana getirilir. Dolaylı somatik embriyogenezde genel olarak oksin hormonu olan 2,4-D kullanılmaktadır (Tisserat, 1985).

Çift çenekli (dikotil) yapıda olan bitkiler ve koniferler globular, kalp, torpedo ve kotiledon olmak üzere dört gelişim evresine sahipken tek çenekli (monokotil) bitkiler ise globular, skutellar, koleoptilar embriyo gelişim evrelerini geçirirler (Raven ve ark., 1999). Somatik embriyolar döllenmiş yumurtadan oluşan embriyodaki gibi globular, kalp, torpedo ve kotiledon aşamalarına sahip olmasına rağmen organogenez ile oluşan sürgünlerden farklı olarak gövde-kök eksenine sahip olup, esas doku ile vasküler bağlantıları olmadığından dolayı dokudan kolaylıkla ayrilabilirler (De Jong ve ark., 1993). İlk olarak somatik embriyogenez yöntemiyle bir tür için embriyo oluşturulması ve bitkiye dönüşebilme potansiyeli araştırıldıktan sonra elde edilen embriyo miktarını artırabilecek bir kültür yöntemi geliştirilir (Redenbaugh, 1990). Burada en çok kullanılan yöntem kontrollü koşullar ışığında biyoreaktörler kullanılarak somatik embriyo üretimidir. Biyoreaktörler; kültür işlemi devam ederken kültür ortamının, $\mathrm{pH}, \mathrm{O}_{2}$ ve diğer gazların ve aynı zamanda sıcaklığın da kontrol edilebildiği düzeneklerden oluşmaktadır. Biyoreaktörler sürekli üretimin gerçekleştirilebildiği, kontaminasyonun en aza indirilebildiği ve aynı zamanda da yüksek oranda homojenizasyonun sağlandığ sistemlerdir (Colgecen ve Toker, 2006). Somatik embriyoların genetik açılımlarının olmaması döllenmeyle oluşan zigotik embriyolara göre en önemli üstünlükleridir. Somatik embriyolar, hem kültüre alınan bitki eksplantının somatik yapıdaki hücrelerinden gelişme gösterirler hem de eksplant alınan bitkinin genetik yapısını taşıdıklarından dolayı da klon oluştururlar (Parrot ve ark., 1991). Buğday (Triticum aestivum L.), çeltik (Oryza sativa L.), asma (Vitis vinifera L.), soya (Glycine $\max$ (L.) Merill), yonca (Medicago sativa L.) ve bezelye (Pisum sativum L.) gibi çeşitli kültür bitkilerinde yüksek miktarlarda somatik embriyo üretiminin gerçekleştirilebildiği birçok farklı yöntem bulunmaktadır (Babaoglu ve ark., 2001). Somatik embriyogenez yoluyla embriyo oluşur ve canlı tohum içerisinde bulunan embriyo ile benzer özellik gösterir. Somatik embriyolar tam bir bitki oluşturabilme potansiyeline sahip oldukları için kaplanmış tohum olarak bitki gelişimlerinde bunlardan yararlanılabilir. Somatik embriyoların koruyucu bileşikler ve besin maddesi içeren özel maddelerle kaplanmış haline sentetik tohum denilir (Kurt, 2015).

\section{Sentetik tohum}

Normalde tohum denildiği zaman dişi ve erkek gametlerin birleşmesi neticesinde oluşmuş olan ve embriyo endosperm ve tohum kabuğu kısımlarından oluşan yapı anlaşılır. Normal bir tohumda embriyonun beslenmesi endosperm yapısı tarafindan sağlanır. Olgun tohumların genel olarak endospermli (besi doku) ve endospermsiz (besi doku bulundurmayan) tohumlar olmak üzere iki farklı çeşidi vardır. Birçok doğal bitki ve kültür bitkisinin tohumları gelişip ana bitkiden ayrıldıktan sonra çimlenmesi adına uygun koşullar sağlansa dahi çimlenemeyip uyku haline girerler. Tohum dormansisiyle (uyku hali) uygun olmayan koşulların atlatılabilmesi sağlandığından dolayı bunun bitkiye büyük bir yararı vardır. Tohumların canlılık ve çimlenme yeteneklerini korudukları süre, bitkilere göre farklılık göstermekle birlikte birçok bitki tohumu canlılıklarını 10-25 yıl koruyabilmektedir. Çimlenen tohumların yüzdesi yaşın artmasıyla beraber azalmaya başlar (Colgecen ve Toker, 2006). Tohumda bulunan embriyo yapısından olgun bir bitkinin gelişmesi için ilk adım olarak çimlenme ve çimlenme için de ilk önce tohumun su alması gereklidir. Hidratasyonla fazla suyun tutulmasından dolayı şişme meydana gelir. Çimlenme esnasında solunum hizı artarken bir yandan da tohumda bulunan depo maddeleri hareketlenir. Depo nişastası (polisakkarit) enzimatik yolla ayrışarak basit şekerlere (monosakkaritler) kadar parçalanır ve oluşan bu şekerler de embriyoya taşınıp büyüme ve gelişme için gerekli olan enerjiyi sağlar (Unal, 2013). Sentetik tohumlar ise normal tohumdan farklı olarak sodyum alginat veya alternatif bir bileşenle kaplanmış somatik embriyolara verilen isimdir (Kiran, 2013) (Şekil 1).

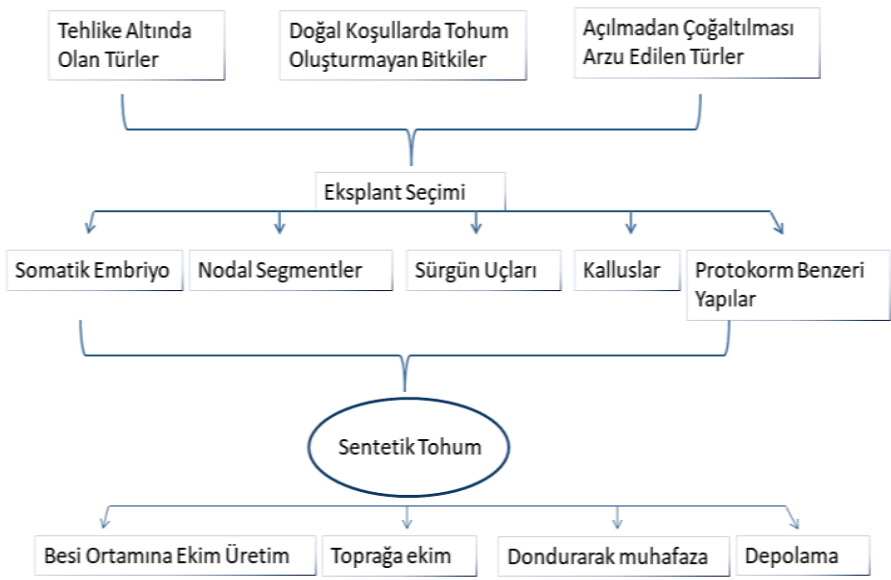

Şekil 1. Sentetik tohum üretim süreçleri ve elde edilen tohumların kullanımı (Saxena ve ark. (2019)'dan değiştirilerek).

Sentetik tohum üretiminde eksplant kaynağını tehlike altında olan türler, tohum oluşturmayan bitkiler ve açılmadan hızlı bir şekilde çoğaltılmak istenen bitkiler gibi bitki kaynakları oluşturmaktadır. $\mathrm{Bu}$ kaynaklardan bitkinin yapısına göre somatik embriyolar, nodal bitki segmentleri, sürgün uçları, kalluslar ve protokorm benzeri yapılar tercih edilerek sentetik tohumlar elde edilebilmektedir. Bu yöntemle elde edilen tohumlar kısa sürede üretilebilirken, doğal tohumlar karmaşık üreme sürecinin son ürünüdür ve yetiştiriciler yeni bir çeşidin gelişmesi için uzun süre beklemek zorundadır (Magray ve ark., 2017). 
Zigotik embriyo çimlenme esnasında besin kaynağı olarak kullanacağı endosperm-depo kotiledonlarına ve tohum kabuğu yapılarına sahiptir. Ancak somatik embriyonun bunların hiçbirine sahip olmaması, zigotik tohum ile sentetik tohum arasındaki farkı gösterir. Sentetik tohum yapımında somatik embriyolar kullanıldığı için bu embriyoların ekim zamanına kadar hem canlı kalmalarını sağlamak hem de bitki gelişimi sürecinde ihtiyaç duyulan besin maddelerini karşılayabilmek için; somatik embriyoların uygun bir jel ile kaplanması, kaplanan embriyoların kurutulduktan sonra ekimi ve somatik embriyoların sıvı içine ekimi gibi çeşitli yöntemler tercih edilmektedir (Babaoglu ve ark., 2001).

\section{Sentetik tohum oluşturulması}

Sentetik tohum oluşturulması; bitki seçimi, somatik embriyogenez, somatik embriyoların olgunlaştırılması ve somatik embriyoların uygun jel kapsülüne alınması (yaygın olarak sodyum alginat ve kalsiyum klorür çözeltisi kullanılır) aşamalarından oluşur. İlk defa Murashige tarafından öne sürülen "yapay tohum" terimi "üretilmiş tohum”, "sentetik tohum” ya da "sentezlenmiş tohum" olarak da bilinmektedir (Murashige, 1978).

Klon oluşturmak amacıyla üretilen bitkilerin çoğaltılabilmesi ve klonlanan özelliklerin devamlılığının sağlanabilmesi için sentetik tohum çalışmaları yapılmıştır (Redenbaugh, 1990). 1978 y1lında Murashige sentetik tohum geliştirme çalışmaları yapmıştır. Sentetik tohum oluşturulmasının bir aşaması olan kapsülasyon işlemi 1981 yılında Lavrence tarafından geliştirilmiştir. Kapsülasyon işleminin geliştirilmesinin ardından hidrojel ile kaplama işlemi Redenbaugh tarafından 1984 yılında gerçekleştirilmiş olup, 1989 yılında ise Fujii tarafindan sentetik tohum ile bitki geliştirilmesi çalışmaları yapılmıştır (Ara ve ark., 2000).

Sentetik tohum üretim maliyeti, araştırma ve geliştirme çalışmalarının basit veya karışık olma durumuna bağlı olarak farklılık gösterir. Örneğin kolay bir şekilde oluşturulabilen bir embriyonun maliyetiyle genetiği düzenli olan bir embriyonun maliyetine bakıldığında aralarında çeşitli farklılıklar bulunmaktadır. Otomasyon sistemlerinin geliştirilmesi, yüksek maliyete rağmen çok miktarlarda üretim yapılması bitki başına maliyeti düşürmektedir. Günümüzde teknolojinin gelişmesiyle birlikte sentetik tohum teknolojisi maliyeti düşmüş ve daha pratik bir teknik haline gelmiştir (Redenbaugh ve ark., 1987; Gray ve Purohit, 1991; Jang ve ark., 2020).

Doku kültüründen elde edilen somatik embriyonun hidrate edilmesiyle ilk olarak sentetik tohumdan bitki oluşturulmuştur. Ancak bu yöntem hem yüksek oranda iş gücü ve maliyet gerektiren, hem de düşük üretim veriminin olduğu bir yöntemdir. Birçok farklı kaplama sistemlerinin denenmesiyle böyle bir sorun aşılmış ve başarılı sonuçlara ulaşılmıştır (Redenbaugh ve ark., 1986; Fujii ve ark., 1989; Fujii ve ark., 1992).

Günümüzde ise sentetik tohumlar, embriyoların hidrojellerle kaplanması ve desikasyon olmak üzere iki farklı yöntemle elde edilebilmektedir. Somatik embriyoların kaplanmasında en yaygın kullanılan madde hidrojel alginattır (Onishi ve ark., 1994). Sentetik tohum çalışmalarında genel olarak daha çok sodyum alginat; uygun vizkosite, hızlı jelleşme, düşük maliyet ve biyolojik olarak uyumluluğu gibi özelliklerinden dolayı tercih edilmektedir (Saiprasad, 2001; Swamy ve ark., 2009).

Uygun gelişim aşamasındaki embriyolar önce sodyum alginat ile karıştırılıp daha sonra kalsiyum klorür solüsyonu içine atılırlarsa 4-6 mm çapında kalsiyum alginat kapsülleri elde edilir (Bornman, 1993). Alginat kapsüllerinin elastik olmamas1, sertleşmesi ve oksijen yetersizliği gibi nedenlerle embriyonun çimlenemediği olumsuz durumlar da gözlenmiştir. Bu sorunu gidermek için somatik embriyoların kaplanmasının amacı gerçek tohumların benzerinin üretilmesi şeklinde açıklanmıştır (Sakamoto ve ark., 1992).

Desikasyon metodunda ise somatik embriyolar ya polietilen glikol (PEG) ve eriyebilir reçine maddeleriyle kaplandıktan sonra, ya da hiçbir madde kaplaması işlemi olmadan direkt olarak kurutulmaktadır. Ancak bu yöntem embriyolar için zararlı olabilmektedir (Bornman, 1993). Sentetik tohum üretim süreci, somatik embriyoların bir kaplama materyaliyle karıştırılmasını kapsar. Embriyolar bu kaplama materyali içinde korunmaktadır (Chawla, 2002). Somatik embriyoların sodyum alginat ve kalsiyum alginat ile kaplanması laboratuvarlar arasında steril materyal transferi ve germplazmların muhafazası açısından oldukça faydalı olmaktadır (Tsvetkov ve ark., 2006).

Sentetik tohum üretilmesinde ana materyal bitkiden doğal olarak oluşan sürgün tomurcukları ve bitki doku kültürüyle oluşturulan somatik embriyolardır. Ancak kültür ortamında çeşitli kimyasallardan yararlanılarak bu yapılardan bütün bir bitki elde edilebilir (Colgecen ve Toker, 2006). Bundan dolayı somatik embriyolar kaplanmış tohum şeklinde kullanılabilme yeteneklerine sahiptir (Parrot ve ark., 1991).

Sentetik tohum oluşturabilmek için somatik embriyolar dışında; nodal bölgeler, sürgün tomurcukları, in vitro çoğaltılmış sürgün yapıları kullanılmakla birlikte protokorm benzeri yapılar ve saçaklı kökler de kullanılabilmektedir (Khor ve Loh, 2005; Colgecen ve Toker, 2006).

Sentetik tohum teknolojisinin esas amac1, somatik embriyoları korumak, saklama ve taşımada kolaylık sağlamaktır (Guerra ve ark., 2001). Ayrica sentetik tohum teknolojisi, in vitro ortamda üretimleri gerçekleştirilen bitkilerin arazi veya sera ortamına aktarımında boyutların küçük olmasından dolayı büyük oranda kolaylık sağlamaktadır (Soneji ve ark., 2002). Sentetik tohumlar normal tohumlar gibi toprak ve besi ortamında çimlendirilip bitki gelişimleri sağlanabilmektedir.

Genelde kurutulmuş ve hidratlanmış (yaş) olarak iki şekilde sentetik tohum üretilmektedir (Rihan ve ark., 2017). Redenbaugh ve arkadaşları, yonca bitkisinde somatik embriyoların bir hidrojel matriksle ile kaplanma işleminin geliştirmiş ve bunun üzerine 1988 yılında patent almışlardır (Redenbaugh ve ark., 1984). Yaş tohum, farklı somatik yapıların sodyum alginat, agar, gelrit ve karragenan gibi çeşitli hidrojel matriksler kullanılarak kapsüle alındığı bir tohum çeşididir. Ancak kapsül oluşturmada en çok kullanılan jel, kalsiyum tuzlarıyla katılaşabilen bir jel matriksi olan sodyum alginattır. Süspansiyon kültüründen elenerek alınan somatik embriyolar sodyum alginat ile karıştırıldıktan ve kalsiyum klorür çözeltisine damlatılır ve daha sonra kalsiyum klorür $\left(\mathrm{CaCl}_{2}\right)$ çözeltisi ile birlikte yüzeyde bir kompleks oluşturur. Böylece içerisinde birkaç propagül bulunduran yuvarlak boncuk şeklini alır. Boncuklar çözelti içerisinde 60 veya 90 dakika tutulup, ardından su ile yıkandiktan sonra hava ile kurutulur ve $4^{\circ} \mathrm{C}$ sicaklıktaki ortamda tutulur. Alginat matriksiyle bir araya getirilip karıştırılacak olan tomurcuklar mümkün olabilecek en küçük boyuta getirilir. İkinci metotda ise, propaguller, sicaklıkla sıvılaşan agar veya gelrit gibi jel matrikslerle karıştırıldıktan sonra kapsüller içine dökülerek soğutulup katılaşması sağlanır (Colgecen ve Toker, 2006). 
Kurutulmuş tohumlar ise, ilk defa Kitto ve Janick tarafından havuç embriyolarının kaplanmasında kullanılan bir yöntemdir (Kitto ve Janick, 1982; Ara ve ark., 2000). Somatik yapıların polietilen glikolle kaplanmasıyla oluşturulan bir tohum çeşididir. Kaplanmış bitki yapıları steril şartlar altında ve teflon bir yüzeyde saatlerce kurumaya bırakıldıktan bir süre sonra kuruyarak ince bir şekil alan karışım son olarak yapay kültür ortamına alınarak re-hidrate edilir ve embriyoların canlı tutulması sağlanır (Colgecen ve Toker, 2006).

\section{Sentetik tohumun avantaj ve dezavantajları}

Sentetik tohum genetik benzerlik, hastalıksız bitki elde edilme olanakları, çalışılmasının kolay olması, üretim maliyetinin düşük olması, seçkin ve nesli tükenmekte olan veya soyları tükenmiş bitki türlerinin germplazmlarının muhafaza edilebilmesi, transgenik bitkilerde orijinal genotipe sahip ana bitkinin somatik embriyo şeklinde korunabilmesi, bitki çoğaltımının kolay yapılabilmesi, direkt olarak araziye aktarım yapılması, boyutlarının küçük olmasından dolayı depolama, işleme, nakletme ve dikme işlemlerinde kolaylık sağlaması, tohumla üretimin mümkün olmadığı bitkilerde de alternatif olarak tohumla üretime olanak sağlaması, bütün üretim aşamalarının otomasyona bağlanabilmesi gibi pek çok avantaja sahiptir (Ara ve ark., 2000; Fang ve ark. 2004; Colgecen ve Toker, 2006; Ravi ve Anand, 2012; Kiran, 2013). Yine sentetik tohumların yılın herhangi bir zamanında ve her mevsiminde üretilebiliyor olması da bir diğer avantajıdır (Magray ve ark., 2017). Ayrıca kararsız genotiplere sahip veya enfeksiyona karşı duyarlı olmayıp tohum kısırlığı gösteren hibritlerin üretiminde sentetik tohum teknolojisinin kullanılabilir olması da sentetik tohumun bir diğer avantajını göstermektedir (Sahoo ve ark., 2012). Sentetik tohum teknolojisinin tüm bu avantajlarının yanı sıra mikroçoğaltım için canlı yapıların az olması, somatik embriyoların aynı zamanlarda gelişememesi, somatik embriyo yapilarında strese tolerans ve dormansi (uyku hali) durumunun eksik olması, uygun olmayan olgunlaşmalar sonucunda kolaylıkla çimlenme ve olgun bitkiye dönüşme kapasitesinin düşük olması gibi bazı dezavantajları da bulunmaktadır (Ara ve ark., 2000; Singh ve ark., 2020).

\section{Kaynaklar}

Ara, H., Jaiswal, U., \& Jaiswal, V. S. (2000). Synthetic seed: Prospects and limitations. Current Science, 78(12), 1438-1444.

Arvas, Y. E., \& Kocacaliskan, I. (2020). Genetiği değiştirilmiş bitkilerin biyogüvenlik riskleri. Türk Doğa ve Fen Dergisi, 9(2), 201-210.

Babaoglu, M., Gurel, E., \& Ozcan, S. (2001). Bitki Biyoteknolojisi I. Doku Kültürü ve Uygulamaları. (pp. 1-374). Konya Selçuk Üniversitesi Basimevi.

Baltaci, A., \& Arslan, M. (2019). Oğulotu (Melissa officinalis) bitkisinde meristem ve somatik embriyo kültürlerinden sentetik tohum elde etme olanakları. Erciyes Tarım ve Hayvan Bilimleri Dergisi, 2(1), 1-10.

Bornman, C. H. (1993). Micropropagation and somatic embryogenesis. In: Hayward M. D., Bosemark N. O., Romagosa I., Cerezo M. (eds) Plant Breeding: Principles and Prospects (pp. 246-260). Springer, London.

Calheiros, M. B. P., Vieira, L. G. E., \& Fuentes, S. R. L. (1994). Effects of exogenous polyamines on direct somatic embryogenesis in coffee. Revista Brasileira de Fisiologia Vegetal, 6(2), 109-114.

Cardoza V. (2008). Tissue culture: The manipulation of plant development. In: Stewart C.N. (eds) Plant Biotechnology and Genetics: Principles, Techniques and Aplications (pp. 113-134). John Wiley \& Sons, USA.

Chawla, H. S. (2002). Introduction to Plant Biotechnology. (pp. 1-538). Science Publishers.

Colgecen, H., \& Toker, M. C. (2006). Sentetik tohum. Anadolu Üniversitesi Bilim ve Teknoloji Dergisi, 7(2), 323-336.

Daud, N., Taha, R. M., \& Hasbullah, N. A. (2008). Artificial seed produc-

\section{Sonuç}

Somatik embriyoların kaplanmasında en uygun jel matriksi olarak sodyum alginat veya alginik asit tercih edilmektedir. Somatik embriyoların bir jel matriksiyle kaplanmasından oluşan sentetik tohumlar bazı sınırlamalarla karşılaşsa da birçok avantajlarının bulunmasıyla ticari olarak üretime katkıda bulunabilir. Hızla gelişen teknoloji ile birlikte yakın bir gelecekte sentetik tohumların CRISPR ve diğer gen transferi teknolojileri gibi biyoteknolojik yöntemlerle birleştirilerek henüz tohum aşamasında iken arzu edilen yönde tohumun dizayn edilmesi daha da mümkün hale gelecek bu sayede çok daha kısa sürelerde genetik yapı olarak iyileştirilmiş tohumların eldesi imkân dâhilinde olabilecektir. Tohumla üretilemeyen bitkilerin geliştirilmesinde sentetik tohum teknolojisinden yararlanılarak bu bitkilerin üretimine katkıda bulunabilmekte ancak çalışmaların incelenmesinden yola çıkılarak bazı sıkıntılarla karşılaşılabileceği görülmektedir. Bunun yanında nesli tükenme tehlikesi altında olan bitkilerden elde edilen somatik embriyoların kaplanması yoluyla neslinin devamı sağlanabilmekte ve böylece orijinal genotip yapısı korunup gelecek nesillere aktarılabilmektedir. Sentetik tohum aslinda her ne kadar bazı sınırlamaları olan bir teknoloji olsa da mevcut avantajlarından dolayı önemli bir yere sahiptir. Sentetik tohum oluşturma mekanizmalarının daha iyi belirlenmesi, daha düşük maliyetle ve daha kolay bir şekilde uygulanabilmesi bu tür çalışmaların daha seri bir şekilde yapılabilmesine olanak sağlayabilecektir.

Teşekkür: Bu derleme makalesi yüksek lisans tezinin literatür taramasından oluşmaktadır ve tez çalışması Aydın Adnan Menderes Üniversitesi, Bilimsel Araştırma Projeleri Birimi tarafindan desteklenmiştir (Proje No: ZRF20037).

Çıkar çatışması: Yazarlar herhangi bir çıkar çatışması olmadığını beyan eder.

Etik beyanı: Bu çalışmada, yazarlar, hiç bir insan ya da hayvan denek kullanılmadığını ve Etik Kurul iznine gerek olmadığını beyan eder.

tion from encapsulated micro shoots of Saintpaulia ionantha Wendl. (African violet). Journal of Applied Sciences, 8(24), 4662-4667.

De Jong, A. J., Schmidt, E. D. L., \& de Vries, S. C. (1993). Early events in higher- plant embryogenesis. Plant Molecular Biology, 22, 367-377.

Fang J., Wetten A., \& Hadley P. (2004). Cryopreservation of cocoa (Theobroma cacao L.) somatic embryos for long-term germplasm storage. Plant Science, 166(3), 669-675.

Finer, J. J. (1995). Direct somatic embryogenesis. In: Gamborg O. L., Philips G. C. (eds) Plant Cell, Tissue and Organ Culture (pp. 91-102). Springer, Berlin, Heidelberg.

Fujii, J. A., Slade, D., \& Redenbaugh, K. (1989). Maturation and greenhouse planting of alfalfa artificial seeds. In Vitro Cellular and Development Biology, 25, 1179-1182.

Fujii, J. A. A., Slade, D., Aguirre-Rascon, J., \& Redenbaugh, K. (1992). Field planting of alfalfa artificial seeds. In Vitro Cellular and Developmental Biology, 28, 73-80.

Ghosh, B., \& Haque, S. M. (2019). Synthetic seeds: An alternative approach for clonal propagation to avoiding the heterozygosity problem of natural botanical seeds. In: Faisal M., Alatar A. A. (eds) Synthetic Seeds (pp. 77-112). Springer, Switzerland.

Gonulsen, N. (1987). Bitki doku kültürleri, yöntemleri ve uygulama alanları. (pp. 1-78). T.C. Tarım ve Köy İşleri Bakanlığı, Menemenİzmir.

Gray, D. J., \& Purohit, A. (1991). Somatic embrtogenesis and development 
of synthetic seed technology. Critical Reviews in Plant Sciences, 10 33-61.

Guerra, M. P., Vesco, L. L. D., Ducroquet, J. P. H. J., Nodari, R. O., \& Reis, M. S. D. (2001). Somatic embryogenesis in Goiaberia serrana: Genotype response, auxinic shock and synthetic seeds. Revista Brasileira de Fisiologia Vegetal, 13(2), 117-128.

Hussein, N. B. M., Huyop, F., \& Kaya, Y. (2020). An easy and reliable method for establishment and maintenance of tissue cultures of Nicotiana tabacum cv. TAPM 26. International Journal of Science Letters, 2(2), 62-71.

Ibrahim, M. S. D., Hartatti, R. S., Rubiyo, Purwito, A., \& Sudarsono. (2013). Direct and indirect somatic embryogenesis on Arabica coffee (Coffea arabica). Indonesian Journal of Agricultural Science, 14(2), 79-86.

Ipekci, K. Z. (2002). Paulownia elongata'nın doku kültürü sistemlerinin optimizasyonu ve sentetik tohum üretimi, Doktora Tezi, (pp. 1-98) İstanbul Üniversitesi, Fen Bilimleri Enstitüsü, Türkiye.

Ipekci, Z., \& Gozukirmizi, N. (2003). Direct somatic embryogenesis and synthetic seed production from Paulownia elongata. Plant Cell Reports, 22, 16-24.

Jalali, N., Naderi, R., Shahi-Gharahlar, A., \& Teixeira da Silva, J. A. (2012). Tissue culture of Cyclamen spp. Scientia Horticulturae, 137, 11-19.

Jang, B. K., Cho, J. S., \& Lee, C. H. (2020). Synthetic seed technology development and production studies for storage, transport, and industrialization of bracken spores. Plants, 9(9), 1079.

Khor, E., \& Loh, C. S. (2005). Artificial seeds. In: Nedovic V., Willaert R. (eds) Aplications of Cell Immobilization Biotechnology (pp. 527-537). Springer Netherlands.

Kiran, R. (2013). Amsonia orientalis Decne. (Apocynaceae)'de somatik embriyogenezis ve sentetik tohum üretimi, Yüksek Lisans Tezi, (pp. 1-85). Kocaeli Üniversitesi, Fen Bilimleri Enstiüsü, Türkiye.

Kitto, S. K., \& Janic, J. (1982). Polyox as an artificial seed coat for a sexual embryos. Horticultural Science, 17, 488.

Kocak, M., Izgu, T., Sevindik, B., Tutuncu, M., Curuk, P., Simsek, O., Kacar, Y. A., Teixeira da Silva, J. A., \& Yalcin Mendi, Y. (2014) Somatic embryogenesis of Turkish Cyclamen persicum Mill.. Scientia Horticulturae, 172, 26-33.

Kumar, G. K. \& Thomas, T. D. (2012). High frequency somatic embryogenesis and synthetic seed production in Clitoria ternatea Linn. Plant Cell, Tissue and Organ Culture, 110, 141-151.

Kurt, O. (2015). Bitki lslahı. (pp. 1-326). Samsun Ondokuz May1s Üniversitesi Ziraat Fakültesi Yayınları.

Magray, M. M., Wani, K. P., Chatto, M. A. \& Ummyiah, H. M. (2017). Synthetic seed technology. International Journal of Current Microbiology and Applied Sciences, 6(11), 662-674.

Mikula, A., \& Rybczyfiski, J. J. (2001). Somatic embryogenesis of Gentiana genes L. The effect of preculture treatment and primary explant origin on somatic embryogenesis of Gentiana cruciata L., G. pannonica (scop) and G. tibetica (King). Acta Phisiologiae Plantarum, 23(1), 15-25.

Mikula, A., Rybczynfiski, J. J., Skierski, J., Latkowska, M. J., \& Fiuk, A (2005). Somatic embryogenesis of Gentiana genus IV. Characterisation of Gentiana cruciata and Gentiana tibetica embryogenic cell suspensions. In: Hvoslef-Eide A. K, Preil W. (eds) Liquid Culture Systems for In Vitro Plant Propagation (pp. 345-358). Springer Netherlands.

Mohammed, K. T., Javed, M. A., Huyop, F., \& Kaya, Y. (2021). Plant tissue culture of Nicotiana tabacum cv. TAPM 26 and its minimum inhibition against herbicide-Dalapon. MANAS Journal of Engineering, 9(1), 3542.

Monnier, M. (1990). Induction of embriyogenezis in callus culture. In: Pollard J. W., Walker J. M. (eds) Plant Cell and Tissue Culture (pp. 141-148). Humana Press, New Jersey.

Murashige, T., \& Skoog, F. (1962). A revised medium for rapidgrowth and bioassays with tobacco tissue culture. Phisiologia Plantarum, 15(3), 473-497.

Murashige, T. (1978). The impact of plant tissue culture on agriculture. In: Thorpe, T. A. (ed) Frontiers of Plant Tissue Culture (pp. 15-26). University of Calgary, Alberta, Canada.

Nakamura, T., Taniguchi, T., \& Maeda, E. (1992). Studies on somatic embryogenesis of coffee by scanning electron microscope. Japanese Journal of Crop Science, 61(3), 476-486.

Onishi, N., Sakamoto, Y., \& Hirrosawa, T. (1994). Synthrtic seeds as and application of mass production of somatic embriyos. Plant Cell, Tissue and Organ Culture, 39, 137-145.

Oktem, H. A., \& Yucel, M. (2012). Bitki gelişiminin yönlendirilmesi. In: Steward N. C., J. R. (ed) Doku Kültürü (pp. 113-134). Nobel Basımevi, Ankara.

Ozcan, S., Babaoglu, M., \& Sancak, C. (2001). Somatik embriyogenezis. In: Babaoglu M., Gürel E., Özcan S. (eds) Bitki Biyoteknolojisi (pp.7188). Selçuk Üniversitesi Basımevi, Konya.

Ozyigit, I. I., \& Yucebilgili Kurtoglu, K. Y. (2020). Particle bombardment technology and its applications in plants. Molecular Biology Reports, $1-17$.

Parrot, W. A., Merkle, S. A., \& Williams, E. G. (1991). Somatic embryogenesis: Potential for usein propagation and gene transfer systems. In: Muray D. R. (ed) Advanced Methods in Plant Breeding and Bitechnology (pp. 158-200). Ist ed, CAB International Press UK.

Raven, P. H., Evert, R. F., \& Eichhorn, S. E. (1999). Biology of plants. (pp. 555-569). WH Freeman and Company/Worth Publishers.

Ravi, D., \& Anand, P. (2012). Production and applications of artificial seeds: A review. International Research Journal of Biological Sciences, 1(5), 74-78.

Redenbaugh, K., Nichol, J. W., Kossler, M. E., \& Paasch, B. D. (1984). Encapsulation of somatic embryos and for artificial seed production. In Vitro Cellular \& Developmental Biology - Plant, 20, 256-257.

Redenbaugh, K., Paasch, B. D., Nichol J. W., Kossler, M. E., Viss, P. R., \& Walker, K. A. (1986). Somatic seeds: Encapsulation of asexual plant embryos. Bio / Technology, 4(9), 797-801.

Redenbaugh, K., Slade, D., Viss, P. R., \& Fujii, J. A. A. (1987). Encapsulation of somatic embryos in synthetic seed coats. Horticultural Science, 22(5), 803-809.

Redenbaugh, K. (1990). Application of artificial seed to tropical crops. Horticultural Science, 25(3), 251-255.

Rihan, H. Z., Kareem, F., El-Mahrouk, M. E., \& Fuller, M. P. (2017). Artificial seeds (principle, aspects and applications). Agronomy, 7(4), 71.

Sahoo, S. L., Rout, J. R., \& Kanungo, S. (2012). Synthetic seeds. In: Sharma H. P., Dogra J. V. V., Misra A. N. (eds) Plant Tissue Culture: Totipotency to Transgenic (pp. 101-114). Agrobios, India.

Saiprasad, G. V. S. (2001). Artificial seeds and their applications. Resonance, 6, 39-47.

Sakamoto, Y., Mashiko, T., Suzuki, A., Kawata, H., \& Iwasaki, A. (1992). Development of encapsulating technology for synthetic seeds. ISHS Acta Horticulturae 319: International Symposium on Transplant Production Systems, Yokohama, Japan. 71-76.

Saxena A., Shukla M., \& Saxena P. (2019). Synthetic seeds: relevance to endangered germplasm conservation in vitro. In: Faisal M., Alatar A. (eds) Synthetic Seeds (pp. 21-60). Springer, Cham.

Schwenkel, H. G., \& Winkelmann, T. (1998). Plant regeneration via somatic embryogenesis from ovules of Cyclamen persicum Mill.. Plant Tissue Culture and Biotechnology, 4, 28-34.

Singh, A. K., Varshney, R., Sharma, M., Agarwal, S. S., \& Bansal, K. C. (2006). Regeneration of plants from alginate-encapsulated shoot tips of Withania somnifera (L.) Dunal, a medicinally important plant species. Journal of Plant Physiology, 163, 220-223.

Singh, D., Pal, S., \& Sinha, A. (2020). Artificial seed/synthetic seed production-brief procedure-advantages and limitations. Biotica Research Today, 2(6), 422-424.

Sokmen, A., \& Gurel, E. (2001). Sekonder metabolit üretimi. In: Babaoglu M., Gurel E., Ozcan S. (eds) Bitki Biyoteknolojisi I., Doku Kültürü ve Uygulamaları (pp. 211-261). Selçuk Üniversitesi Basımevi, Konya.

Soneji, J. R., Rao, P. S., \& Mhatre, M. (2002). Germination of synthetic seeds of pineapple (Ananas comosus L. Merr.). Plant Cell Reports, 20, 891-894.

Sule, R. (2005). Farklı oksin çeşitlerinin Yonca (Medicago sativa L.)'da somatik embriyo oluşumuna etkisi üzerine bir araştırma, Yüksek Lisans Tezi, (pp. 1-70). Mustafa Kemal Üniversitesi, Fen Bilimleri Enstitüsü, Antakya, Türkiye.

Swamy, M. K., Balasubramanya, S., \& Anuradha, M. (2009). Germplasm conservation of patchouli (Pogostemon cablin Benth.) by encapsulation of in vitro derived nodal segments. International Journal of Biodiversity and Conservation, 1(8), 224-230.

Takamura, T., Miyajima, I., \& Matsuo, E. (1995). Somatic embryogenesis of Cyclamen persicum Mill. "Anneke" from aseptic seedlings. Plant Cell Reports, 15, 22-25.

Tekin, H. I. (2015). Bitki doku kültürü. T.C. Tarım ve Köy İşleri Bakanlığı Alata Bahçe Kültürleri Araştırma Enstitüsü Müdürlüğü, Erdemli- 
Mersin, https://arastirma.tarimorman.gov.tr/alata/Belgeler/Digerbelgeler/DokuK\%C3\%BClt\%C3\%BCr\%C3\%BCH.\%C4\%B0.Tekin.p df, Son erișim 18 Temmuz 2021.

Tisserat, B. (1985). Embryogenesis, organogenesis, and plant regeneration. In: Dixon R. A. (ed) Plant Cell Culture: A Practical Approach (pp. 79 106). Information Retrieval Limited Press. Oxford, England.

Tsvetkov, I., Jouve, L., \& Hausman, J. F. (2006). Effect of alginate matrix composition on regrowth of in vitro-derived encapsulated apical microcuttings of hybrid apsen. Biologia Plantarum, 50 (4), 722-724.

Unal, M. (2013). Bitki Angiosperm Embriyolojisi. (pp. 1-280). Nobel Akademik Yayıncılık.

Uysal, H., Seyis, F., \& Kurt, O. (2007). Tarla bitkilerinde melezleme bariyerlerinin aşılmasında alternatif bir yöntem: embriyo kültürü. $O M \ddot{U}$ Ziraat Fakültesi Dergisi, 22(1), 116-122.

Uysal, H. (2021). In vitro propagation of black cumin (Nigella sativa L.) plants. Genetika, 53(1), 295-303.

Cite as/Atıf şekli: Erdem, M., \& Uysal, H. (2021). Sentetik tohum. Front Life Sci RT, 2(2), 68-74. 